some of Brazil's overseas debt into obligations of restraint. Countries such as the Netherlands have already embarked along that route. The biodiversity treaty is a framework within which more comprehensive agreements might be reached, for the Amazon and elsewhere. But everything is a special case, requiring special study. That should be the cornerstone of the way in which the biodiversity treaty functions. Meanwhile, Mr John Major, the British prime minister, is surely right to advocate a programme of more vigorous taxonomic research in regions such as the Amazon (and it is needlessly mean, even by its own standards, for British Friends of the Earth to describe his Rio speech as "empty waffle").

None of this touches the poverty of the poor. Strong's fault is that he has encouraged, especially among the governments of the developing countries, the belief that compensation for custodianship will meet the capital costs of development. That is a gigantic and cruel mistake, especially with a Rio agenda innocent of the issue of population growth. But is not rapid population growth in the developing countries itself a consequence of their poverty? Nobody disputes that in the rich world, the benign demographic transition from high to low rates of birth and death has invariably followed rising prosperity and improved public health. Yet many governments of developing (and quickly growing) countries could be trying harder even as things are. Sooner rather than later, there will have to be a UN conference on that issue as well.

\section{Moratorium ending}

\section{The impending Washington summit has a daunting list of nuclear issues that must be tackled.}

Now that the Cold War has ended, why does nuclear testing continue? That is an issue raised this week by the executive committee of the Pugwash Organization which, unlike other international pressure groups, is almost laconic in what it says in public. Specifically, Pugwash has taken fright that it will soon be a year since President Mikhail Gorbachev (remember him?) volunteered, on behalf of the Commonwealth of Independent States, a one-year moratorium on testing. Since then, President Boris Yeltsin had said that Russian tests will resume when the moratorium expires in September. Pugwash asks that the moratorium should be extended at the Washington summit this week, and that the United States should join in.

That, of course, would be an excellent development; there is more than an element of the bizarre in the continued and repeated testing of weapons whose purposes have been confused (or even made nugatory) by the events of the past few months. But, sadly, the summit planned for Washington has even more urgent nuclear business to attend to. Plans for a further bilaterally agreed reduction of strategic arms appear to have foundered on the issue of missiles carrying several warheads, while confusion persists about the role of Russia as the nuclear custodian of other ex-Soviet republics, the Ukraine conspicuously, but also Khazakstan. Will they eventually become members of the Nuclear Non-Proliferation Treaty (NPT), and if they do, will it be as nuclear or nonnuclear powers?

That question cannot be left unanswered for much longer. Three years from now, the NPT will lapse unless its members elect for its continuation (and for the restrictions it imposes on them). Already there are worrying signs of renewed hankering after independent facilities for making bombs Iraq last year, reports of attempts illicitly to sell ex-Soviet fissile material by Vienna-based agents only last week. The big danger is that the nonproliferation regime will turn into a leaky sieve long before its sponsors (Russia, presumably, still among them) have worked out a way of selling its virtues to the nonnuclear members of the treaty. A moratorium on testing would help powerfully in that direction.

\section{Genome propaganda}

\section{Concealing the truth without lying is an old art, now spreading in the US human genome project.}

By now there can hardly be a researcher who has not heard some account of the unfortunate circumstances behind the resignation in April of Dr James Watson as director of the US human genome project. But the account of the resignation in the current issue of Human Genome News, the project's official newsletter, recalls the old propaganda technique of reporting the facts without telling the truth. Nowhere does this account mention what most readers already know from other sources, that Watson resigned after Bernadine Healy, the director of the National Institutes of Health, launched an investigation into his financial holdings. Not even reading between the lines provides a hint of friction between the two.

Instead, the newsletter treats Watson's departure as a routine transition. It quotes him to the effect that directing both the genome project (based in Bethesda, Maryland) and the Cold Spring Harbor Laboratory (in New York state) had become too burdensome for him and his family. It also notes that Watson had told his advisory committee as early as last January - before the controversy arose — that he was thinking of leaving. Although that is true, it is also true that the very press officer who wrote the newsletter account told reporters at the time not to take the comment too seriously; Watson often threatens to resign, she explained.

No one expects the genome project's official newsletter to wallow in gossip. But by pretending that there was no dispute at all - when even Healy was willing to discuss the situation openly - the newletters belittles its reseearcher-readers, who are grown-up people and who deserve an accurate and balanced report, and reflects badly on the credibility of the enterprise. Perhaps the lesson from this shabby episode is that the $\$ 7$ million a year the United States is spending on the ethics of genome research is not enough. 